\title{
Profile of lifestyle of older elderly persons
}

\section{Abstract}

Introduction: Lifestyle has been widely studied in recent years, especially in the context of longevity and aging well. Objective: The aim of this study was to analyze the lifestyle profile of older elderly persons and the relationship between lifestyle and chronic diseases. Method: A cross-sectional study evaluating 132 older persons aged over 74.6 years, who were resident of the Capão Redondo district of São Paulo, was carried out. The study was conducted in 23 institutions such as churches, community centers, parks, nursing homes and residences. All participants completed two questionnaires, with the first based on lifestyle and the second on socio-economic classification, and also answered some questions about the presence and control of non-communicable chronic diseases (NCDs). Result: the mean age was $78.8( \pm 4.5)$ years and the respondents had a mean BMI of 25.5( \pm 5.5$)$. Most were women from social classes $C$ and D. A total of 46 were former smokers, seven were smokers, and 82 had NCDs, with heart diseases the most prevalent. The mean lifestyle questionnaire score was $30.2( \pm 3.5)$. There was no statistical difference in scores between those with NCDs and those that did not suffer from such diseases. The physical activity component had the lowest score, followed by the nutrition component. The prevalence of NCDs was significantly higher for smokers and former smokers than for those who had never smoked. Conclusion: The majority of older persons demonstrated an excellent lifestyle with healthy habits. Even those with a diagnosed NCD had a good lifestyle. Cardiovascular diseases were the most prevalent in this population. The risk of NCD was greater for smokers and former smokers than for those who had never smoked.
Marilza Amaral Henrique de Souza ${ }^{1}$

Elias Ferreira Porto ${ }^{1}$

Eduardo Luiz de Souza²

Kathleen Ingrid da Silva ${ }^{3}$
Keywords: Health of the Elderly. Health Promotion. Longevity. Life Style.

\footnotetext{
Centro Universitário Adventista de São Paulo, Curso de pós-graduação stricto sensu Promoção da Saúde, Qualidade de Vida e Estilo de Vida. São Paulo, SP, Brasil.

2 Faculdade de Tecnologia do Centro de Educação Estadual Paula Souza - CEETEPS, Curso de Graduação em Comércio Exterior. Barueri, SP, Brasil.

3 Centro Universitário Adventista de São Paulo, Curso de graduação em Fisioterapia. São Paulo, SP, Brasil.
}

Correspondence

Marilza Amaral Henrique de Souza

Email:marilza.ahs@gmail.com 


\section{INTRODUCTION}

The increase in the elderly population requires a change in political, economic and social paradigms and strategies, so that elderly persons can have the expectancy of a healthy life with the minimum of physical disabilities and/or special needs care. ${ }^{1-4}$

If elderly persons themselves and the various sectors of society do not contribute to these changes, aging may be marked by increasing social and economic demands caused by disabilities and non-communicable chronic diseases (NCD). Such conditions can result in complications and sequelae that compromise the Independence and autonomy of elderly persons, which can be costly to these individuals, their families and health systems. ${ }^{5}$

Aging with the minimization of chronic diseases can be influenced by immutable and mutable factors. Immutable factors include gender, age and genetic inheritance. Mutable factors relate to the lifestyle of the individual or a particular group. These factors involve practices related to nutrition, physical activity, preventive behavior, social relationships and stress management. Such practices are enhanced by socioeconomic, cultural and environmental conditioning factors. ${ }^{3,4}$

From this perspective, it can be argued that a study which analyzes the lifestyle of older elderly persons is useful for the diagnosis of the factors that contribute to the fact that such individuals surpass the life expectancy of their generation, as well as identifying those that are harmful to an active and healthy life and which could be prevented, treated and controlled.

\section{METHOD}

The present study forms part of the "multifactorial profile of older elderly persons" and is a field study, with a quantitative approach, explanatory profile, and cross-sectional design. Data collection was carried out following the approval of the Research Ethics Committee of UNASP/SP, under number 871.829. This analysis complied with resolution $466 / 12$ of the National Health Council. ${ }^{6}$

Data collection was performed from March to June 2015 and carried out in churches, community centers, parks, and nursing and residential homes located in the region of Capão Redondo, situated in the Technical Health Department of Campo Limpo, in the south region of the city of São Paulo. To be included in the study subjects had to meet the following criteria: be aged 74.6 years or older and be a resident of the Capão Redondo region of São Paulo. Subjects with clinical and psychological conditions that meant they were incapable of responding to the study questionnaires were excluded. The 132 older elderly persons included in this sample were visited in the institutions and locations mentioned and, after being duly informed about the protocol of the study and signing a clear and informed consent form, responded to interviews and questionnaires about the presence and control of non-communicable chronic diseases, their health conditions, sociodemographic status and lifestyle.

The Nahas Individual Lifestyle Profile questionnaire was used to evaluate lifestyle. This is a questionnaire on lifestyle which assesses the following components: "nutrition", "physical activity", "preventive behavior", "social relationships" and "stress management". Each component is worth a maximum of nine points. The sum of the five components can reach a maximum of 45 points.

The questionnaire is comprised of 15 questions that are divided in a uniform manner into the five components mentioned above. Each question uses a Likert answer scale that varies from " 0 " to " 3 ". The values " 0 " and " 1 " are linked to a negative lifestyle profile while responses " 2 " and " 3 " are associated with a positive lifestyle. The questionnaire considers the lifestyle of the individual during the majority of his or her life.

To characterize the sample and identify the profile of the study participants, such as gender, ethnicity, marital status and educational level, the 
socioeconomic questionnaire of the Associação Brasileira de Empresas de Pesquisa $(\mathrm{ABEP})^{8}$ (the Brazilian Association of Research Companies) was used.

Data is presented as mean and standard deviation. The symmetry of the data was analyzed using the Kolmogorov-Smirnov Test. The comparison between groups was performed using the t-test or analysis of variance considering the number of variables to be analyzed. To identify the weight of each variable in terms of its contribution to longevity, multivariate regression was performed. Only variables that were significant in this model were submitted to analysis of risk. $P$ values $\leq 0.05$ were considered statistically significant.

\section{RESULTS}

The mean age of the participants in the sample was $78.8 \pm 4.5$ and the majority were women. In terms of socioeconomic classification, four older elderly persons belonged to class A2; 14 to class $\mathrm{B} 1 ; 18$ to $\mathrm{B} 2 ; 21$ to $\mathrm{C} 1 ; 47$ to $\mathrm{C} 2$ and 20 to $\mathrm{D}$. With respect to health conditions, 46 were ex-smokers, seven were smokers and 82 participants said they had some type of NCD (table 1).

Table 1. Characterization of biological and socioeconomic variables of sample. São Paulo, state of São Paulo, 2015.

\begin{tabular}{|c|c|}
\hline Variables & $\mathrm{N}=132$ \\
\hline Height (m) & $1.6( \pm 0.10)$ \\
\hline $\operatorname{BMI}\left(\mathrm{k} / \mathrm{m}^{2}\right)$ & $25.5( \pm 5.5)$ \\
\hline Gender $(\mathrm{M} / \mathrm{F})$ & $42 / 90$ \\
\hline Socioeconomic Class A2 & 4 \\
\hline Socioeconomic Class B1 & 14 \\
\hline Socioeconomic Class B2 & 18 \\
\hline Socioeconomic Class C1 & 29 \\
\hline Socioeconomic Class C2 & 47 \\
\hline Socioeconomic Class D & 20 \\
\hline Ex-smokers & 46 \\
\hline Smokers & 7 \\
\hline Non-communicable chronic disease $(+)$ & 82 \\
\hline
\end{tabular}

The mean Nahas Individual Lifestyle Profile score was $30.2( \pm 3.5)$ points. Analyzing the components separately, a mean score of $4.1( \pm 3)$ was found for "physical activity", with CI 95\% (3.6 to 4.6). The mean score for "nutrition", was 6.1( \pm 4.1 ), with CI 95\% (5.8 to 6.5). The mean "social relationships" score was $7( \pm 2.2)$ with CI $95 \%$ (6.0 to 6.8), while for "stress management" the mean score was $8.0 \pm 1.6$ with CI 95\% (6.6 to 7.2). In "preventive behavior" the mean score was $8.0 \pm 2.2$ with CI of $95 \%$ (6.6 to 7.4 ). The score for the "physical activity" component was significantly lower than the scores of the other components $(p<0.0001)$. The mean score of the "nutrition" component was also significantly lower than the scores of the "preventive behavior" and "stress management" components $(p<0.001)$ (Figure 2). 


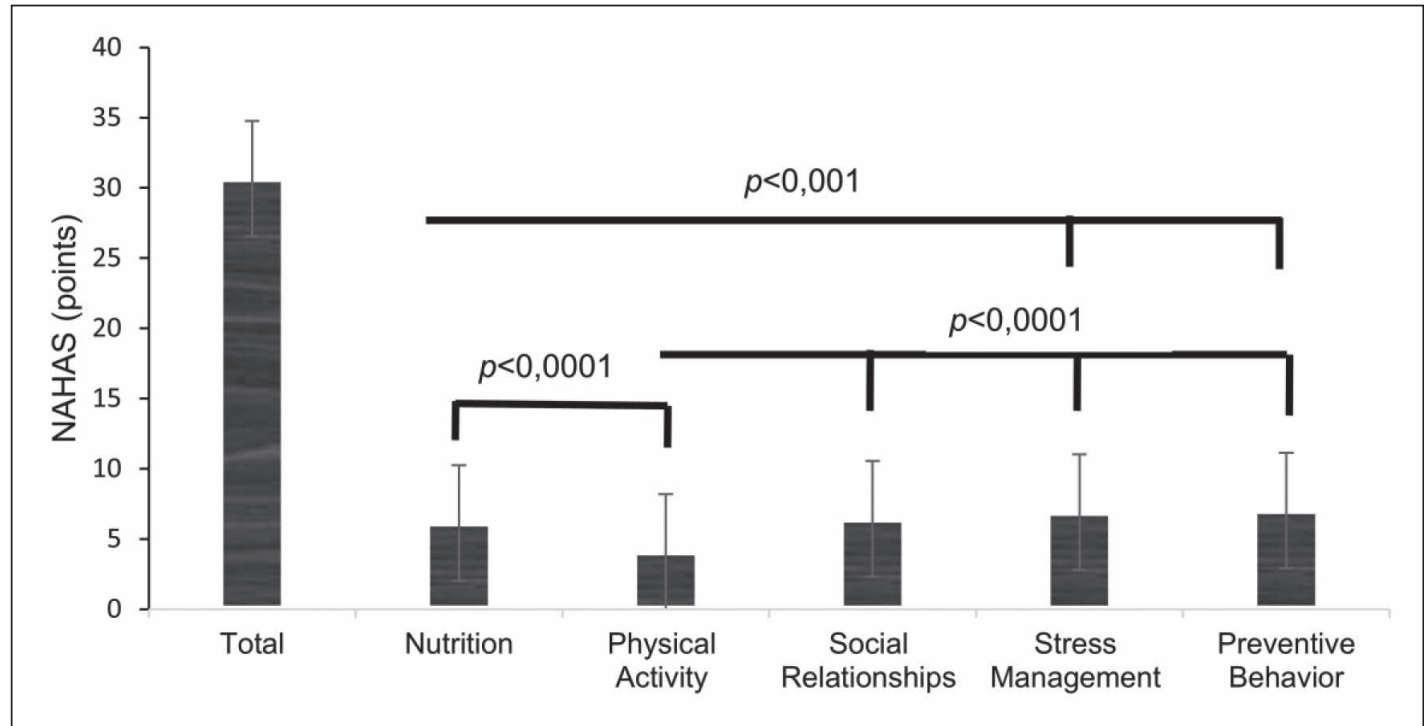

Figure 1. Lifestyle of studied population evaluated by Nahas Individual Lifestyle Profile. São Paulo, state of São Paulo, 2015.

Of the 132 participants, $62 \%$ said they had been diagnosed with some type of noncommunicable chronic disease. No significant differences were found based on the proportions of men and women or the marital status or age of those who either did or did not have a noncommunicable chronic disease.

Among those who said they had a NCD, $74.3 \%$ had a cardiovascular illness; $26.8 \%$ Diabetes Mellitus; $23 \%$ dyslipidemias; $10.9 \%$ chronic obstructive pulmonary disease; $6.0 \%$ thyroid diseases and $4.8 \%$ cancer.

There was no significant difference in the lifestyle of groups with and without non- communicable chronic diseases. For the group with non-communicable chronic diseases, the mean Nahas Individual Lifestyle Profile score was $30( \pm 7$ ), with CI95\% (28 to 32). The group without non-communicable chronic diseases had a Nahas Individual Lifestyle Profile score of $32( \pm 6)$, with CI 95\% (30 to 33) (Figure 2).

The proportion of smokers with NCD was $85.7 \%$, while $76.1 \%$ of elderly ex-smokers suffered from such illnesses. Among those that had never smoked, the proportion with NCD was $51.8 \%$. There was a greater predominance of cardiovascular diseases among smokers and exsmokers than among those who had never smoked (figure 3). 


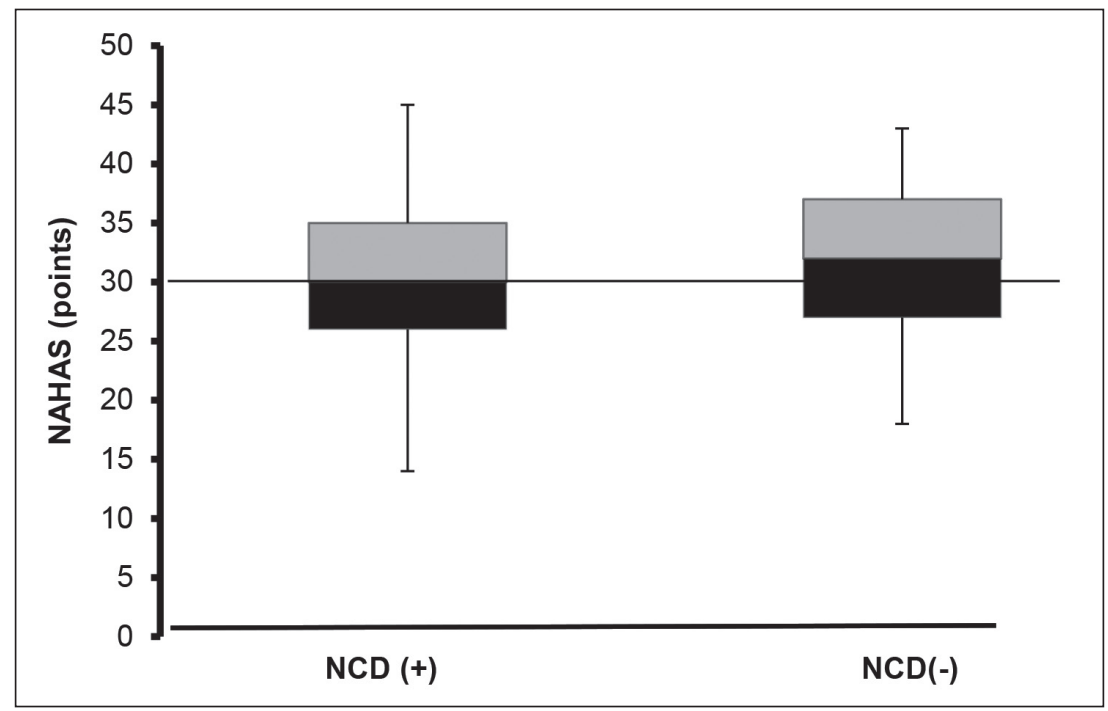

Figure 2. Analysis of Nahas Individual Lifestyle Profile for individuals with and without non-communicable chronic diseases. São Paulo, state of São Paulo, 2015.

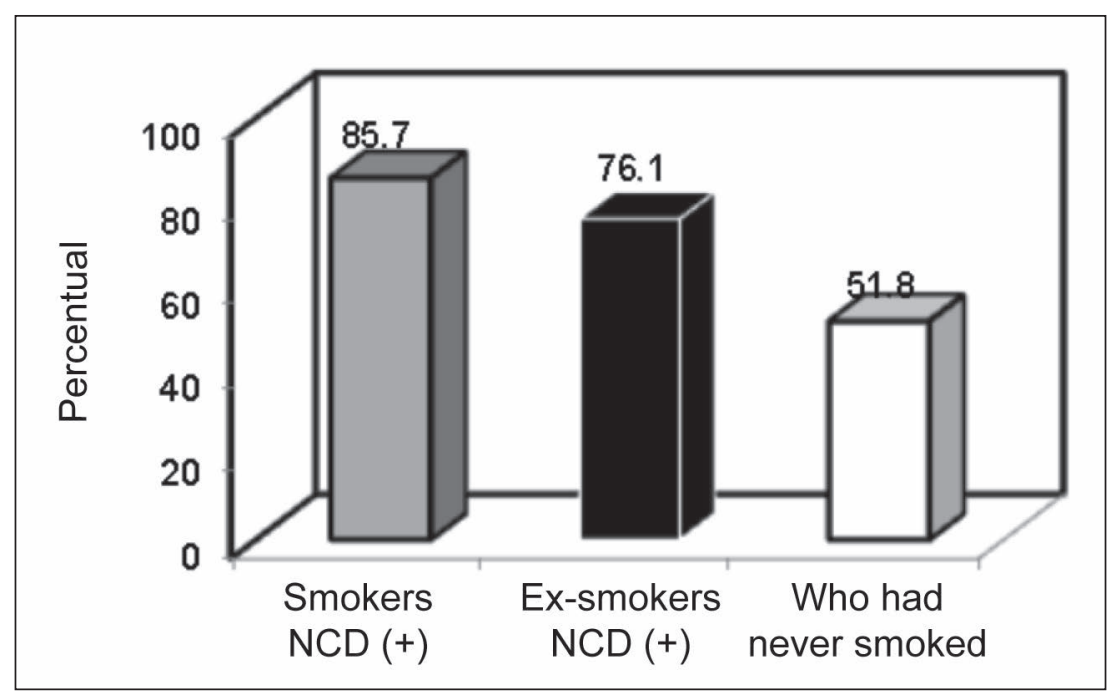

Figure 3. Proportion of smokers, ex-smokers and those who had never smoked with non-communicable chronic diseases (NCD). São Paulo, state of São Paulo, 2015.

The risk of a smoker devolving a NCD in relation to an individual who had never smoked was OR 11.3 with CI of $95 \%$ (1.3 to 19.9$)$ and $p=0.01$. In terms of ex-smokers in comparison with those who had never smoked, the risk was OR5.1, with CI of $95 \%$ (2.0 to 12.9) and $p=0.03$. Stopping smoking (ex-smokers $v s$ smokers) reduced the risk by OR 0.1 in comparison with those who continued smoking (CI of 95\% (0.7 to 8.2).

\section{DISCUSSION}

The present study analyzed the Nahas Individual Lifestyle Profile in relation to the diagnosis of non-communicable chronic diseases in 132 older elderly persons. The main result found was that the participants had a good lifestyle, achieving a mean Nahas Individual Lifestyle Profile score of 30.2 points. The highest scores were registered 
in the components of social support, preventive behavior, stress management and quality of diet. The physical activity component had the lowest score in the evaluation of the lifestyle of the participants. Cardiovascular diseases were the most prevalent NCDs and tobacco use significantly increased the risk of such diseases.

In terms of the analysis of lifestyle based on the Nahas Individual Lifestyle Profile questionnaire, the results show that the older elderly persons evaluated had a positive lifestyle profile, or in other words, their nutritional state, preventive behavior, stress management and social relationships were satisfactory. Such profiles can a determining factor for longevity. ${ }^{7}$

Studies have found that elderly persons with satisfactory social networks of support and friendship can increase their chances of longevity by $22 \%$. Another interesting finding is the fact that having more and closer friends is a protective factor for the cardiovascular health of older men, when compared with more solitary individuals. Elderly women with more friends throughout life had a lower incidence of cognitive problems, compared to those with smaller and more fragile social networks. ${ }^{9} 10$

Irrespective of gender, age and ethnicity, elderly persons with a stable circle of friendships preserve their memories to twice the extent of less socially integrated elderly individuals. Generally speaking, close, satisfactory social relationships reduce morbidity and mortality and are vital sources of emotional strength and overall well-being. ${ }^{3,11}$

Another factor that promotes health and longevity is preventive behavior, which involves collective and individual actions of caring for one's own health. This type of behavior involves primary, secondary and tertiary prevention and treatment of illnesses that are common to aging individuals. $^{12}$
Primary prevention includes, for example, respecting traffic laws and abstaining from tobacco and alcohol use. Secondary prevention involves actions aimed at screening for early detection of chronic diseases, while tertiary prevention means seeking proper medical treatment. All these forms of prevention help reduce the risk of disability and were assessed by the Nahas Individual Lifestyle Profile questionnaire, revealing an excellent mean score. This result demonstrates that these practices are associated with longevity.,12

With respect to smoking, results showed that the use of tobacco significantly increased the risk of chronic diseases. This is the most important modifiable risk factor for NCDs for young and old people and is the leading cause of preventable death. Smoking is a risk factor for an extensive and growing list of diseases, and the effects of its use are cumulative and long lasting. There is no safe level of tobacco use, but it is known that a longer exposure time results in a greater risk of developing NCDs. One of the most important changes that elderly smokers could make to their lifestyle was ceasing tobacco use. Only 5.3\% of the population analyzed continued to smoke. ${ }^{13,14}$

One negative result observed in this study was that the physical activity component of the population analyzed presented a much lower average than all the other components. Physical inactivity is prevalent among the elderly. Modern lifestyles involve spending most of one's free time in sedentary activities, such as sitting watching television for long periods. The main problem with a sedentary lifestyle is that it has proven to be an important risk factor for obesity and increased cholesterol and blood sugar levels. Those who cease to be sedentary, meanwhile, decrease the risk of death from cardiovascular diseases by $40 \%$. It is possible that if older persons performed more physical activity, the prevalence of NCDs would be lower. ${ }^{15-17}$ 
The results for the nutrition component show that, although the diets of the analyzed population were not excellent, they were generally composed of fruit, vegetables and food that was rich in fiber and had a low quantity of saturated fats. It is possible that these individuals adopted this style of diet late in life, perhaps following the diagnosis with a NCD. Diets rich in saturated fat and salt, and that are low in fruit and vegetables and have an insufficient quantity of fibers and vitamins, combined with a sedentary lifestyle, are the greatest risk factors for such diseases. ${ }^{18,19}$

Another important result was that cardiovascular illnesses were the most prevalent of the NCDs in the sample. According to the Sociedade Brasileira de Cardiologia (the Brazilian Society of Cardiology), diseases of the circulatory system were among the top ten causes of death in 2009 in both developing and developed countries. These illnesses accounted for $28.7 \%$ of deaths in developing countries and $26.6 \%$ in developed countries. Brazilian data showed that cardiovascular diseases accounted for one third of all mortalities and nearly $30 \%$ of all deaths in the 20-59 year age group, affecting the most productive phase of an adult life. ${ }^{12,13}$

There are several risk factors for cardiovascular disease. Some of these are modifiable and relate to the individual's lifestyle, such as habits and behaviors that can be prevented, treated and controlled. Other risk factors are immutable and include, for example, family history and ethnicity. These factors, as well as contributing to the development of cardiovascular diseases, can be challenges for the treatment and control of such illnesses. ${ }^{20}$

Although the prevalence of cardiovascular disease was found to be high in the sample (74.3\%), the majority of elderly respondents said they went to the doctor, underwent routine checkups and took prescribed medication to control the disease. In addition to these preventive actions, other behavior adopted by the elderly subjects of this study favored the treatment and control of cardiovascular diseases. It appears that even with cardiovascular diseases, a healthy lifestyle was found to be a positive factor for longevity. ${ }^{7,12}$

The clinical implications of this study are based on the finding that a lifestyle focused on healthy habits can be a contributing factor for longevity. Such lifestyles should therefore be encouraged among young people and young adults, as the earlier a healthy lifestyle is adopted, the better health conditions will be during aging.

The main limitations of the present study include the fact that there was no evaluation of the period of time for which the lifestyle in question had been adopted, although the applied questionnaire referred to the longest possible time in which the individual remembered having had followed his or her lifestyle. There are, however, few studies in Brazil about the lifestyle of older elderly persons. Therefore, the aim of the present study was to analyze the lifestyle of such individuals, and its relationship with noncommunicable chronic diseases.

\section{CONCLUSION}

In summary, we can conclude that in the present study the majority of elderly persons had an excellent lifestyle with healthy habits. Even those diagnosed with a NCD had a good lifestyle. Cardiovascular diseases are the most prevalent type of illnesses for this population. The risk of a NCD was higher for smokers and non-smokers than for those who had never smoked. It is suggested that future studies continue this theme by investigating the impact of an active lifestyle on aging, preferably adopting a longitudinal approach.

The results suggest that a lifestyle based around health habits is a contributing factor for longevity. Public policies aimed at stimulating and promoting a healthy lifestyle among young people and young adults should therefore be encouraged, as it appears that the younger such lifestyles are adopted, the better health conditions will be during aging. 


\section{REFERENCES}

1. Ministério dos Negócios Estrangeiros. Programa das Nações unidas para o desenvolvimento. Relatório do Desenvolvimento Humano 2014. Sustentar o Progresso Humano: Reduzir as Vulnerabilidades e Reforçar a Resiliência. Camões Instituto da Cooperação da Língua Portugal. New York (NY), USA: 2014.

2. Brasil. Ministério da Saúde, Secretaria da Atenção à Saúde, Departamento de Atenção Básica. Envelhecimento e saúde da pessoa idosa. Brasília, DF: MS; 2006.

3. World Health Organization. Active ageing: a policy framework. Suzana Gontijo, tradução. Brasília, DF: OPAS;2009.

4. Nahas MV. Atividade física, saúde e qualidade de vida. $4^{a}$ ed. Londrina: Midiograf ; 2008.

5. Brasil. Ministério da Saúde, Secretaria de Atenção à Saúde, Departamento de Ações Programáticas e Estratégicas. Atenção à saúde da pessoa idosa e envelhecimento. Área Técnica Saúde do Idoso. Brasília, DF: MS; 2010.

6. Conselho Nacional de Saúde. Resolução 466. Diretrizes e normas regulamentadoras de pesquisas envolvendo seres humanos. Saúde Legis 12 dez 2012.

7. Nahas MV, Barros MVG, Francalacci VL. O pentáculo do bem-estar. Base conceitual para avaliação do estilo de vida de indivíduos ou grupos. Rev Bras Ativ Fís Saúde 2000;5(2):48-59.

8. Associação Brasileira de Empresas de Pesquisa. Critério Padrão de Classificação Econômica Brasil [Internet]. São Paulo: FGV EESP; 2008 [acesso em 22 ago 2015];[1 p.]. Disponível em: http://cmicro.fgv.br/sites/cmicro.fgv.br/files/file/ CCEB \%20FGV\%20(25-6-2012).pdf

9. Souza DA, Santos EC. Relacionamentos de amizade e coping entre jovens adultos. Psic Teor Pesqui 2012;28(3):345-56.

10. Crooks VC, Lubben J, Petitti DB, Little D, Chiu V. Social network, cognitive function, and dementia incidence among elderly women. Am J Public Health 2008;98(7):1221-7.

11. Ertel KA, Glymour MM, Berkman LF. Effects of social integration on preserving memory function in a nationally representative U.S. elderly population. Am J Public Health 2008;98(7):1215-20.
12. Brasil. Ministério da Saúde, Secretaria de Vigilância à Saúde. Secretaria de Atenção à Saúde. Diretrizes e recomendações para o cuidado integral de doenças crônicas não-transmissíveis: promoção da saúde, vigilância, prevenção e assistência. Brasília,DF:MS; 2008.

13. Andrade JP, Mattos LAP, Carvalho AC, Machado CA, Oliveira GMM. Programa Nacional de Qualificação de Médicos na Prevenção e Atenção Integral às Doenças Cardiovasculares. Arq Bras Cardiol [Internet] 2013 [acesso em 23 ago 2015];100(3):203-11. Disponível em: http://www.scielo.br/pdf/abc/v100n3/v100n3a01.pdf

14. Feitosa RCL, Pontes ERJC. Survey of the life-styles and factors associated with the occurrence of cancer in smokers from the city of Sidrolândi. Ciênc Saúde Coletiva 2011;16(2):605-13.

15. Toscano JJO, Oliveira ACC. Qualidade de vida em idosos com distintos níveis de atividade física. Rev Bras Med Esporte [Internet] 2009 [acesso em 23 ago 2015];15(3):169-73. Disponível em: http://www.scielo.br/scielo.php?pid=S1517$86922009000300001 \&$ script $=$ sci_abstract $\&$ tlng $=$ pt

16. De Tata V. Age-related impairment of pancreatic beta-cell function: pathophysiological and cellular mechanisms. Front Endocrinol [Internet] 2014 [acesso em 23 ago 2015];5:1-8. Disponível em: http://journal. frontiersin.org/article/10.3389/fendo.2014.00138/full

17. Ornish DI, Scherwitz LW, Billings JH, Brown SE, Gould KL, Merritt TA, et al. Intensive lifestyle changes for reversal of coronary heart disease. JAMA 1998; 280(23):2001-7.

18. Brasil. Ministério da Saúde, Secretaria de Atenção à Saúde, Departamento de Atenção Básica. Guia alimentar para a população brasileira. $2^{\mathrm{a}}$ ed. Brasília,DF: MS; 2014.

19. Azevedo ECC, Diniz AS, Monteiro JS, Cabral PC. Padrão alimentar de risco para as doenças crônicas não transmissíveis e sua associação com a gordura corporal: uma revisão sistemática. Ciênc Saúde Coletiva [Internet] 2014 [acesso em 23 set 2015];19(5):1447-58. Disponível em: http://www. scielo.br/scielo.php?script $=$ sci_arttext\&pid $=$ S1413 81232014000501447\&lng=en\&nrm=iso

20. Sociedade de Cardiologia de São Paulo. Fatores de risco para doenças cardiovasculares [Internet]. São Paulo: SOCESP; 2014 [acesso em 23 out 2014]. Disponível em: http://www.socesp.org.br/prevencao/ fatores-de-risco/\#.V8mBldQrI_4 